\title{
Restricted visiting reduces nosocomial viral respiratory tract infections in high-risk neonates
}

\begin{abstract}
To the Editor:
Viral respiratory tract infections (VRTIs) are more prevalent in the neonatal intensive care unit (NICU) than previously thought, with up to $52 \%$ of infants having evidence of viral carriage $[1,2]$. We and others have previously reported nosocomial VRTIs can cause significant morbidity [3], particularly in preterm infants, including escalation of respiratory support, longer hospital stay, increased requirement for home oxygen and greater healthcare costs $[1,4]$. Viral carriage in the airways of children and adults may have few or no symptoms $[3,5]$, potentially implicating them as an inadvertent source of nosocomial VRTI when visiting the NICU. During pandemics, such as the recent H1N1 influenza pandemic, this could have devastating consequences [3]; most VRTI outbreaks on NICUs trigger measures to reduce spread, including visitor restrictions $[6,7]$. No studies have explored the impact of planned visitor restrictions on NICU nosocomial VRTIs. We aimed to study the impact of planned NICU winter visitor restrictions during the H1N1 pandemic.
\end{abstract}

This study was carried out using routine electronic patient data from two UK tertiary NICUs, covering the Trent Perinatal Network annual birth population of 26000, between August 2007 and May 2013. Their combined capacity is 16 intensive care, eight high dependency and 14 special care cots. The NICUs are part of two large teaching hospitals with 1700 beds providing a population of 4-5 million with all specialist healthcare services including paediatric and adult intensive care. Normal NICU visiting allows $24 \mathrm{~h}$ access for the parents of the baby with a 2:00-8:00pm visiting time for family and friends including children. During the period of maximal H1N1 community prevalence in the UK (October to March in 2009-2010 and 2010-2011), planned visitor restrictions were in place with only parents allowed, aiming to minimise cross-contamination in this high-risk population of babies. The same restrictions were in place during the same winter period of 2011-2012 following the second more severe H1N1 winter [8] and the uncertainty of a possible third peak. Throughout the study period, identical infection prevention policies were in place in both hospitals including hand hygiene, isolation procedures for infected babies, and staff or visitors with infections were advised to stay away until well. Babies clinically suspected of having a VRTI were isolated and screened, using real-time PCR from respiratory secretions, and declared positive as previously described [4]. Babies are not readmitted to the NICU after discharge.

We used a Poisson generalised additive model (GAM) to model the number of cases per 2-month period as a function of several explanatory variables to estimate an incidence rate ratio (IRR) for changes in the incidence of infection during restrictions. The model included a thin plate spline to capture the underlying temporal trend in the rate of infection, a categorical variable to model seasonal variations in the rate of infection by 2 -month period, and variables to model NICU workload intensity (operationalised as the percentage of all bed days classed as intensive care) and the number of positive VRTI samples across all hospital inpatients (including hospital-acquired infections). The latter two variables were logarithmically transformed to make them more normally distributed. The total number of NICU bed days in each period was used as an offset term in the Poisson model to account for variations in the number of babies at risk of developing infection.

@ERSpublications

Restricting visitors on the neonatal intensive care unit to parents only during a worldwide pandemic resulted in a $39 \%$ reduction in nosocomial viral respiratory tract infections in neonatal patients. These findings need validating in a prospective trial. http://ow.ly/i8t $430 \mathrm{n} 2 \mathrm{c} 2 \mathrm{v}$

Cite this article as: Szatkowski L, McClaughry R, Clarkson M, et al. Restricted visiting reduces nosocomial viral respiratory tract infections in high-risk neonates. Eur Respir J 2019; 53: 1801874 [https://doi.org/ 10.1183/13993003.01874-2018]. 
TABLE 1 Number of episodes of PCR-positive viral respiratory tract infections from inpatients between 2007 and 2013 in two large teaching hospitals in Nottingham, UK

\begin{tabular}{|c|c|c|c|c|c|c|c|c|c|c|c|c|c|c|c|c|c|c|c|c|c|c|c|c|c|}
\hline \multirow[t]{2}{*}{ Virus } & \multicolumn{2}{|c|}{2007} & \multicolumn{4}{|c|}{2008} & \multicolumn{4}{|c|}{2009} & \multicolumn{4}{|c|}{2010} & \multicolumn{4}{|c|}{2011} & \multicolumn{4}{|c|}{2012} & \multicolumn{2}{|c|}{2013} & \multirow[t]{2}{*}{ Total } \\
\hline & $\begin{array}{l}\text { Aug- } \\
\text { Sept }\end{array}$ & $\begin{array}{l}\text { Oct- } \\
\text { Dec }\end{array}$ & $\begin{array}{l}\text { Jan- } \\
\text { March }\end{array}$ & $\begin{array}{c}\text { April- } \\
\text { June }\end{array}$ & $\begin{array}{l}\text { July- } \\
\text { Sept }\end{array}$ & $\begin{array}{l}\text { Oct- } \\
\text { Dec }\end{array}$ & $\begin{array}{l}\text { Jan- } \\
\text { March }\end{array}$ & $\begin{array}{l}\text { April- } \\
\text { June }\end{array}$ & $\begin{array}{l}\text { July- } \\
\text { Sept }\end{array}$ & $\begin{array}{l}\text { Oct- } \\
\text { Dec" }\end{array}$ & $\begin{array}{l}\text { Jan- } \\
\text { March" }\end{array}$ & $\begin{array}{l}\text { April- } \\
\text { June }\end{array}$ & $\begin{array}{l}\text { July- } \\
\text { Sept }\end{array}$ & $\begin{array}{l}\text { Oct- } \\
\text { Dec }\end{array}$ & $\begin{array}{c}\text { Jan- } \\
\text { March" }\end{array}$ & $\begin{array}{l}\text { April- } \\
\text { June }\end{array}$ & $\begin{array}{l}\text { July- } \\
\text { Sept }\end{array}$ & $\begin{array}{l}\text { Oct- } \\
\text { Dec" }\end{array}$ & $\begin{array}{l}\text { Jan- } \\
\text { March" }\end{array}$ & $\begin{array}{l}\text { April- } \\
\text { June }\end{array}$ & $\begin{array}{c}\text { July- } \\
\text { Sept }\end{array}$ & $\begin{array}{l}\text { Oct- } \\
\text { Dec }\end{array}$ & $\begin{array}{l}\text { Jan- } \\
\text { March }\end{array}$ & $\begin{array}{l}\text { April- } \\
\text { May }\end{array}$ & \\
\hline Inf & 3 & 12 & 27 & 15 & 0 & 93 & 16 & $4(1)$ & 13 & 12 & 1 & 1 & 0 & 43 & 27 & 0 & 0 & 1 & 44 & 11 & 0 & 69 & $113(1)$ & 18 & 525 \\
\hline InfPan & 0 & 0 & 0 & 0 & 0 & 0 & 0 & 0 & 0 & $67(4)$ & 10 & 0 & 0 & 118 & 37 (1) & 0 & 0 & 0 & 0 & 0 & 0 & 0 & 0 & 0 & 237 \\
\hline PF & 16 & 24 & 9 & 41 & 12 & 8 & 32 & 24 & 22 & 17 & $16(1)$ & 39 & 5 & 8 & 15 & $28(1)$ & 12 & 21 (1) & 17 (2) & $31(1)$ & 16 & 24 & $73(5)$ & 67 & 588 \\
\hline Rhino & $47(3)$ & $68(4)$ & $68(1)$ & $57(4)$ & 75 & $107(6)$ & 112 (1) & $60(5)$ & $78(4)$ & 127 (1) & 76 & $97(3)$ & 65 (3) & 121 & 126 (1) & $88(3)$ & $68(7)$ & 147 (2) & 134 (1) & $102(9)$ & $80(1)$ & $161(3)$ & $102(7)$ & 97 (1) & 2333 \\
\hline RSV & 19 & 237 & 57 & 1 & 11 & 297 (1) & 50 & 6 & 4 & 202 & 55 (1) & 3 & 0 & 218 & 167 & 5 & 0 & 186 & 188 (3) & 8 & 5 & 242 (1) & 112 & 19 & 2098 \\
\hline Other & 12 & 31 & 54 & 26 & 14 & 82 & $94(3)$ & 28 & 10 & 26 & 58 & 20 & 4 & 7 & 71 & 20 & 5 & 20 & 82 & $74(1)$ & 25 (1) & 76 (1) & 78 & 98 & 1021 \\
\hline Total & 100 & 376 & 216 & 144 & 112 & 594 & 308 & 128 & 131 & 456 & 218 & 163 & 77 & 515 & 445 & 145 & 92 & 378 & 471 & 237 & 128 & 577 & 491 & 300 & 6802 \\
\hline
\end{tabular}

All patient samples, excluding those from the neonatal intensive care unit (NICU), are shown per quarter with the NICU viruses identified shown in parentheses. Inf: influenza A, B and C; InfPan: H1N1 pandemic influenza; PF: parainfluenza 1-4; Rhino: rhinovirus; RSV: respiratory syncytial virus; Other: adenovirus, cytomegalovirus, coronavirus, Epstein-Barr virus, herpes simplex virus and murine pneumonia virus. : approximate periods of visiting restrictions to the NICU. 
We built a full model containing all potential explanatory variables and then used a backwards fitting approach to build a parsimonious model taking $\mathrm{p}<0.05$ as an indicator of parameter significance. The Akaike information criterion (AIC) was used to compare alternative models, examine our model for evidence of overdispersion to ensure the Poisson distribution was appropriate, and examine residuals for normality and evidence of remaining autocorrelation.

We used the function "gam" from the library "mcgv" in the statistical software R version 3.0.2 to model the data [9]. Ethical approval was granted by the University of Nottingham Medical School Ethics Committee (Nottingham, UK).

A total of 6808 respiratory viruses were identified by PCR with no significant differences between 3 -monthly positive samples during the restricted winter periods (median 434, interquartile range (IQR) 285-582) compared to nonrestricted winter periods (median 451, IQR 338-482; $\mathrm{p}=0.93$ ). In total, 77313 NICU bed days were delivered (mean \pm SD $2209 \pm 135$ per 2 -month period) with $22.1 \pm 3.7 \%$ classed as intensive care. 100 separate VRTI episodes were identified in 95 NICU patients $(2.9 \pm 2.6$ cases per 2 -month period) (table 1). Rhinovirus accounted for $33 \%$ of all patient samples but $73 \%$ of neonatal samples. H1N1 peaked in the winter of 2010-2011 but only one infant (with ventilator-dependent chronic lung disease, who died) tested positive during this restriction period.

The results of the GAM models used to estimate the IRR for the change in rate of infection during restriction periods were: parsimonious model IRR 0.61 (95\% CI 0.38-0.99, AIC 147.9; adjusted $\mathrm{R}^{2}=0.28$, $\mathrm{p}=0.044$ ), which included a thin plate spline for underlying trend and percentage intensive care days; the full model IRR 0.60 (95\% CI 0.36-0.99, AIC 149.8; adjusted $\mathrm{R}^{2}=0.26, \mathrm{p}=0.046$ ), which included the parsimonious model variables and categorical seasonal variable and total positive VRTI samples. The parsimonious model suggests a 39\% reduction in the incidence of infection in the periods when restricted visiting arrangements were in place.

Our study, one of the first to report a planned period of visitor restriction during a worldwide influenza pandemic, suggests stricter NICU visiting practice could reduce nosocomial VRTIs by 39\%. These babies have never left the NICU and so probably acquired the infection from visitors or staff, many of whom may have subclinical infection $[3,5]$. There is significant variability in visiting practices and dealing with outbreaks of VRTIs on the NICU [6,7] and in other clinical settings [10, 11]. Minimising the risks of nosocomial VRTIs could have an impact on neonatal bronchopulmonary dysplasia and length of hospital stay, and could reduce the need for home oxygen, which is double that of noninfected preterm infants [4]. An observational study in a 527-bed tertiary children's hospital demonstrated a similar $37 \%$ reduction in nosocomial VRTIs following introduction of a standardised visitation policy, although this were not as strict as in our study [12]. Neither that study nor the present one was able to address the impact staff viral carriage could have on nosocomial VRTI.

Using a robust method accounting for underlying temporal and seasonal trends to isolate the intervention is a major strength of our study. Another strength of the modelling approach includes factoring in the population burden, using positive hospital admissions as a crude marker, and NICU workload intensity. No other infection prevention strategies were introduced during this period and the study window includes winter periods before and after planned restrictions. However, the main limitation of our study is the low event rate (VRTI) with borderline significance, although the inclusion of important confounders in the Poisson model is a strength. Other limitations include being based on two centres only and potentially only a small part of the variance has been captured $\left(\mathrm{R}^{2}=0.28\right)$. The uptake of antivirals and influenza vaccination could not be assessed, although these may not have a significant impact between seasons, particularly as the H1N1 vaccine programme started after the first peak incidence [13].

Our results raise the possibility that nosocomial VRTI in the NICU can be reduced by visitor restrictions and this could be an important preventative measure during pandemics [3]. These findings need further validation and could also be extended to studies exploring the impact of this policy throughout the year with a focus on reducing bronchopulmonary dysplasia, home oxygen need and healthcare costs, whilst minimising the impact on family-centred care and parent wellbeing [14].

Lisa Szatkowski ${ }^{1}$, Rebecca McClaughry ${ }^{2}$, Martin Clarkson ${ }^{2}$ and Don Sharkey $\odot^{2}$

${ }^{1}$ Division of Epidemiology and Public Health, University of Nottingham, Nottingham, UK. ${ }^{2}$ Academic Child Health, School of Medicine, University of Nottingham, Nottingham, UK.

Correspondence: Don Sharkey, Academic Child Health, University of Nottingham, E floor East, University Hospital, Nottingham, NG7 2UH, UK. E-mail: don.sharkey@nottingham.ac.uk

Received: Oct 032018 | Accepted after revision: Nov 082018 
Acknowledgements: Shair Zinna (Nottingham University Hospitals NHS Trust, Nottingham, UK) assisted with some of the data collection.

Conflict of interest: None declared.

Support statement: D. Sharkey was supported by a clinical senior fellowship from the Higher Education Funding Council for England. Funding information for this article has been deposited with the Crossref Funder Registry.

\section{References}

1 Bennett NJ, Tabarani CM, Bartholoma NM, et al. Unrecognized viral respiratory tract infections in premature infants during their birth hospitalization: a prospective surveillance study in two neonatal intensive care units. J Pediatr 2012; 161: 814-818.

2 Ronchi A, Michelow IC, Chapin KC, et al. Viral respiratory tract infections in the neonatal intensive care unit: the VIRIoN-I study. J Pediatr 2014; 165: 690-696.

3 Enstone JE, Myles PR, Openshaw PJ, et al. Nosocomial pandemic (H1N1) 2009, United Kingdom, 2009-2010. Emerging Infect Dis 2011; 17: 592-598.

4 Zinna S, Lakshmanan A, Tan S, et al. Outcomes of nosocomial viral respiratory infections in high-risk neonates. Pediatrics 2016; 138: e20161675.

5 Hayward AC, Fragaszy EB, Bermingham A, et al. Comparative community burden and severity of seasonal and pandemic influenza: results of the Flu Watch cohort study. Lancet Respir Med 2014; 2: 445-454.

6 French CE, McKenzie BC, Coope C, et al. Risk of nosocomial respiratory syncytial virus infection and effectiveness of control measures to prevent transmission events: a systematic review. Influenza Other Respir Viruses 2016; 10: 268-290.

7 Tan S, Clarkson M, Sharkey D. Variation in visiting and isolation policies in neonatal units: a U.K. nationwide survey. Pediatr Infect Dis J 2018; 37: e20-e22.

8 Green HK, Andrews N, Fleming D, et al. Mortality attributable to influenza in England and Wales prior to, during and after the 2009 pandemic. PLoS ONE 2013; 8: e79360.

9 Wood S. Generalized Additive Models: An Introduction with R. Boca Raton, Chapman and Hall/CRC, 2017.

10 Liu V, Read JL, Scruth E, et al. Visitation policies and practices in US ICUs. Crit Care 2013; 17: R71.

11 Pong AL, Beekmann SE, Faltamo MM, et al. Visitor restriction policies and practices in children's hospitals in North America: results of an Emerging Infections Network survey. Infect Control Hosp Epidemiol 2018; 39: 968-971.

12 Washam M, Woltmann J, Ankrum A, et al. Association of visitation policy and health care-acquired respiratory viral infections in hospitalized children. Am J Infect Control 2018; 46: 353-355.

13 Green HK, Ellis J, Galiano M, et al. Critical care surveillance: insights into the impact of the 2010/11 influenza season relative to the 2009/10 pandemic season in England. Euro Surveill 2013; 18: 20499.

14 Gooding JS, Cooper LG, Blaine AI, et al. Family support and family-centered care in the neonatal intensive care unit: origins, advances, impact. Semin Perinatol 2011; 35: 20-28. 